\title{
Lethal ataxia with deafness and optic atrophy
}

INSERM

\section{Source}

INSERM. (1999). Orphanet: an online rare disease and orphan drug data base. Lethal ataxia with deafness and optic atrophy. ORPHA:1187

Lethal ataxia with deafness and optic atrophy (also known as Arts syndrome) is characterized by intellectual deficit, early-onset hypotonia, ataxia, delayed motor development, hearing impairment and loss of vision due to optic atrophy. 